\title{
EPIC-PHASE: a Model to explore Irrigation Strategies
}

\author{
A. M. Santos ${ }^{1}$; M. Cabelguenne ${ }^{2}$; F. L. Santos ${ }^{1}$; M. R. Oliveira ${ }^{1}$; R. P. Serralheiro ${ }^{1}$; M. A. Bica ${ }^{3}$ \\ ${ }^{1}$ Universidade de Évora, Apartado 94, 7002-554 Évora, Portugal; e-mail of corresponding author: asantos@uevora.pt \\ ${ }^{2}$ INRA Centre de Recherches de Toulouse BP27-F31326, Castanet Tolosan, France; e-mail: cabelgue@toulouse.inra.fr \\ ${ }^{3}$ INIA Estação de Culturas Regadas de Alvalade do Sado, 7565 Alvalade do Sado, Portugal
}

(Received 16 November 1998; accepted in revised form 9 December 1999)

\begin{abstract}
The erosion productivity impact calculator phase (EPIC-PHASE) model has been used to simulate, using 1972 to 1994 climatic date, two irrigation strategies with a non-limited water supply: (1) a standard strategy based on simple decision rules advisable for moderately deep soils of the Lauragais region (France) and in the Alentejo region (Portugal); and (2) a model strategy based on the daily development of soil water depletion and daily water stress intensity predicted by the model. At Lauragais, the results show that for the same level of yield it would have been possible with the model to save $73 \mathrm{~mm}$ on average, equivalent of two irrigations per year, compared to the standard strategy. These savings are due to an increased soil water contribution during the cycle and to an earlier end of the irrigation supply. At Alentejo, the results show that for the same level of yield as obtained with the standard strategy, it would have been possible with EPIC-PHASE model to save $100 \mathrm{~mm}$ of water on average, equivalent of two irrigations per year due to an increased use of soil water during the cycle. Although the results are from simulations it is proved that the standard strategy is inadequate. Regarding the environmental impact, the model management allows for an increase in the level of water depletion at harvest, delaying the risk of percolation and nitrogen losses during the refill period. The EPIC-PHASE model proved to be a tool capable of defining an irrigation schedule better adapted to the Mediterranean region.
\end{abstract}

C) 2000 Silsoe Research Institute

\section{Introduction}

Simulation models of crop growth and development, such as the erosion productivity impact calculator phase (EPIC-PHASE) model (Cabelguenne \& Debaeke, 1996; Cabelguenne \& Deumier, 1996; Cabelguenne et al., 1997), can be an efficient and useful tool for managing irrigation, especially in water-limited situations. The EPIC-PHASE model was developed and tested to schedule irrigation on maize at the INRA Station d'Agronomie of Toulouse in Auzeville, Southwest of France, from 1972 to 1994 and was calibrated and validated, from 1994 to 1996, at Alvalade do Sado, Southwest of Portugal (Santos et al., 1996, 1999). Alvalade do Sado is under a sub-humid Mediterranean climate. Annual rainfall from 1972 to 1994 was highly variable, ranging from 353 to $890 \mathrm{~mm}$ and concentrated throughout the year from October to April. The average rainfall from May to September was $105 \mathrm{~mm}$, which represents $20 \%$ of the average annual amount of $532 \mathrm{~mm}$. The average climatic deficit-evapotranspiration (ET) less rainfall-from May to September was $789 \mathrm{~mm}$. In Auzeville, the climate is also Mediterranean but with annual rainfall ranging from 415 to $1000 \mathrm{~mm}$. During the period considered above, the average rainfall from May to September was $304 \mathrm{~mm}$, representing $43 \%$ of the average annual amount of $715 \mathrm{~mm}$. The average climatic deficit from May to September was $448 \mathrm{~mm}$.

These two extreme Mediterranean regions provided excellent conditions to test and evaluate the potential of the EPIC-PHASE model to define an irrigation scheduling strategy adapted to each situation. At each site, the model was tested to schedule irrigation under two different water application strategies. The scheduling strategies were designed to attain the same level of yield traditionally obtained in the two regions but achieving an economy of water supply due to a better management of the soil water storage during the crop cycle through the use of the model. 


\section{Material and methods}

\subsection{The irrigation scheduling model}

The EPIC-PHASE model is a modified version of the EPIC model (Williams et al., 1989) which incorporates the effects on harvest index of water stress at different crop physiological phases.

This modified version is well adapted for irrigation scheduling and for optimizing the use of available water according to a set objective, and for taking into account the crop water stress sensitivity at each growth stage. The EPIC-PHASE model contains additional crop parameters, resulting in a better simulation of water stress effects on growth and yield throughout the growing season. Although details of the model have been presented elsewhere (Cabelguenne \& Debaeke, 1995), the program flowchart is presented in Fig. 1.

As well as the additional crop parameters, the model considers four phenological phases expressed as fractions of the whole growing season. With regard to crop root development, the EPIC-PHASE model also includes new parameters, which account for the shape of the root system, simulating either a rather cylindrical system such as found with sunflowers or a conical system similar to the maize root system. The model simulates the ability of roots to absorb water in soils of different texture.

Compared with the original model, EPIC-PHASE model includes new parameters representing the sensitivity to water stress at each phase. These parameters affect the harvest index according to the duration (stress days) and intensity of stress using an average response slope during the phases. But, as an option, the harvest index sensitivity can be modulated through the use of other parameters specifying a water stress threshold for each phase. The model will choose between two different response slopes, depending on the relative magnitude of the water stress intensity (moderate or strong) compared with the threshold value (Fig. 1).

The larger the duration and the intensity of stress, the earlier the plant begins to senesce. A parameter is included in EPIC model to simulate the normal senescence starting at the end of the vegetative period. The EPIC-PHASE model includes an additional parameter which allows the model to initiate leaf senescence before the end of the vegetative period, at a time defined by another parameter expressed as a fraction of the growth cycle.

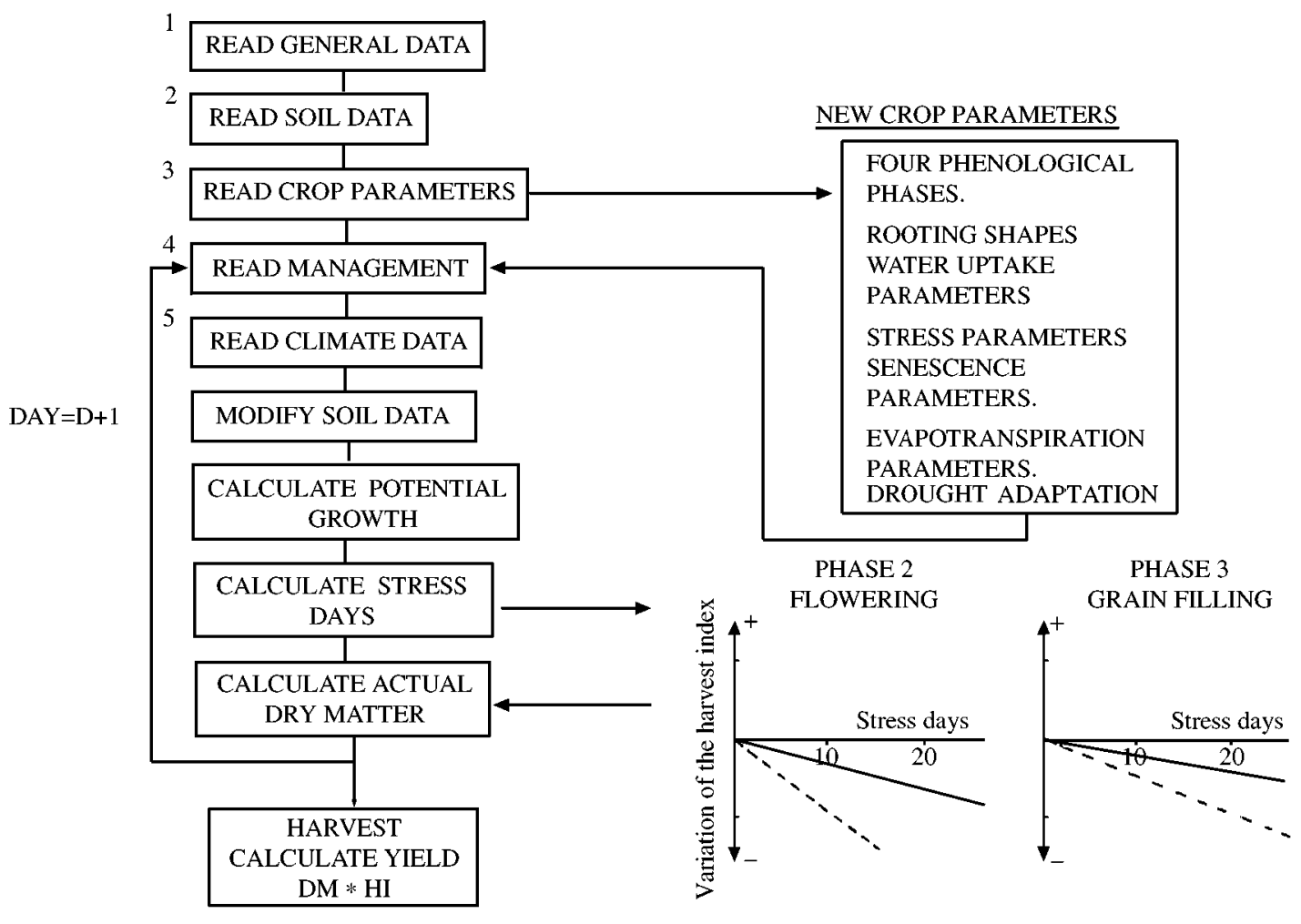

Fig. 1. Program flowchart for the erosion productivity impact calculator phase (EPIC-PHASE) model: DM, dry matter; HI, harvest index; —-, effect on the harvest index of a moderate water stress; ----, effect of a high water stress 
Regarding evapotranspiration (ET), two new parameters were added which allow for more crop water uptake than the calculated potential ET values and also for a reduction of crop water use without yield reductions. These parameters are used to express the ability of crops such as sunflower to use more without reducing yield as part of a process of drought adaptation.

\subsection{Irrigation strategies}

The EPIC-PHASE model was used in Alvalade do Sado (Southwest of Portugal, $37^{\circ} 5^{\prime} \mathrm{N}, 8^{\circ} 24^{\prime} \mathrm{W}$ ) and in Auzeville (Southwest of France, $43^{\circ} 5^{\prime} \mathrm{N}, 1^{\circ} 25^{\prime} \mathrm{E}$ ), from 1972 to 1994, to schedule irrigation and simulate the performance of two irrigation strategies under conditions of non-limiting water supply and applied on moderately deep soils.

On both sites, one standard irrigation strategy was realized according to simple decisions rules applied to moderately deep soils of each region. In Auzeville, $35 \mathrm{~mm}$ was applied weekly and, at Alvalade do Sado, $50 \mathrm{~mm}$. The other irrigation strategy was a model strategy based on the daily development of soil water depletion and daily water stress intensity predicted by the model. Since crop-available water depends on the soil characteristics, the rooting depth, and the crop water extraction capacity (Maertens \& Cabelguenne, 1971), similar levels of soil water depletion may generate different stress intensities. Consequently, it is important to know both the soil water depletion and water stress intensity (Cabelguenne et al., 1997). The computed daily water stress intensity is the ratio between the offer and the demand of water and range from 1 (no stress) to 0 (maximum stress). With this strategy, $35 \mathrm{~mm}$ was applied in Auzeville when the daily water stress intensity was less than $0 \cdot 9$, and $50 \mathrm{~mm}$ was applied in Alvalade do Sado when the daily water stress intensity was less than 0.95 . These values of daily water stress intensity were fixed according to experimental work (Santos et al., 1999). The high value of the daily water stress intensity at Alvalade do Sado is due to the high climatic deficit of this region.

The EPIC-PHASE model was used first to simulate under non-irrigated conditions to precise the water stress and yields variability during the 1972-1994 period.

\section{Results}

\subsection{Water stress and yield under non-irrigated conditions}

The simulations with EPIC-PHASE model show that irrigation is needed to grow maize in Alvalade do Sado (Table 1). The grain yield was zero for all the years accounted for due to the lack of water in the soil profile during the months of June through October. For Auzeville, the yields were very variable, with a minimum of $4.7 \mathrm{t} / \mathrm{ha}$ in 1989 and a maximum of $11.7 \mathrm{t} / \mathrm{ha}$ in 1979 . The simulated grain yield was strongly related to the climatic deficit for each region.

Figure 2 shows the consequences of non-irrigation on daily average water stress intensity at flowering and grain filling crop stage. At Alvalade do Sado, the average daily water stress development was similar for all the years, being markedly influenced by the regularity of the climatic deficit. At the flowering stage, the values of the average daily water stress were already extremely high $(0 \cdot 38-0 \cdot 50)$ due to insufficient precipitation received during the spring season. They were very close to those simulated at the grain filling stage as observed afterwards. At Auzeville, the average daily water stress development was extremely irregular, in accordance with the variability of the climatic deficit (Fig. 2). At the flowering stage, the values of the average daily water stress were lower $(0 \cdot 8-1 \cdot 0)$, indicating the effects of the precipitation received during May and June. During the grain-filling stage, the average daily water stress was also high $(0 \cdot 65-0 \cdot 90)$ due to the low level of water on the soil.

\subsection{Comparison between the irrigation strategies}

\subsubsection{Alvalade do sado}

The simulations with the EPIC-PHASE model show that, under the standard strategy, $550 \mathrm{~mm}$ of water was applied each year due to the regularity of the climatic deficit and the simulated yield was $11 \cdot 1 \mathrm{t} / \mathrm{ha}$ on average (Table 1). The proportion of the average soil water used before irrigation, that is, the ratio between the actual deficit and the total water storage (water in the root zone between field capacity and the permanent wilting point), was low (21-35\%) with a mean of $25 \%$ (Fig. 3). At harvest, this proportion was $42 \%$ on average (Fig. 3).

Table 1 shows that under the model strategy and for the same level of yield as obtained with the standard strategy, $450 \mathrm{~mm}$ was applied each year, representing an economy of $100 \mathrm{~mm}$ of water and the equivalent of two irrigations per year. The end of irrigation season in both strategies occurs at the beginning of September. This relatively late ending of irrigation is due to the poor level of water storage (proportion of water used was around $50 \%$ ) and to low rainfall. So, the water savings with the model strategy are due to an increased use of soil water throughout the cycle. With regard to the proportion of the average soil water used, values between 31 and $54 \%$ before irrigation were simulated (Fig. 3). At harvest, this proportion was also higher (average of 54\%) than the use with the standard strategy (Fig. 3). 
Table 1

Simulated yield under non-irrigated and irrigated conditions, amount of water supplied according to the standard and the model strategies; climatic deficit (May-September)

\begin{tabular}{|c|c|c|c|c|c|c|c|c|c|c|}
\hline \multirow[b]{3}{*}{ Year } & \multicolumn{6}{|c|}{ Water applied, $\mathrm{mm}$} & \multirow{2}{*}{\multicolumn{2}{|c|}{ Climatic deficit, $\mathrm{mm}$}} & \multirow{2}{*}{\multicolumn{2}{|c|}{$\begin{array}{c}\text { Yield under irrigation } \\
\text { Standard or Model, t/ha }\end{array}$}} \\
\hline & $\begin{array}{r}\text { Yield } \\
\text { non-irrig }\end{array}$ & $\begin{array}{l}\text { under } \\
\text { ation, t/ha }\end{array}$ & \multicolumn{2}{|c|}{ Alvalade } & \multicolumn{2}{|c|}{ Auzeville } & & & & \\
\hline & Alvalade & Auzeville & Standard & Model & Standard & Model & Alvalade & Auzeville & Alvalade & Auzeville \\
\hline 1972 & 0 & $8 \cdot 3$ & 550 & 450 & 175 & 130 & 856 & 238 & $10 \cdot 8$ & $11 \cdot 9$ \\
\hline 1973 & 0 & $9 \cdot 1$ & 550 & 450 & 245 & 125 & 831 & 438 & $11 \cdot 9$ & $11 \cdot 6$ \\
\hline 1974 & 0 & $11 \cdot 7$ & 550 & 450 & 105 & 35 & 869 & 246 & $12 \cdot 1$ & $12 \cdot 4$ \\
\hline 1975 & 0 & $8 \cdot 4$ & 550 & 450 & 210 & 140 & 817 & 377 & $10 \cdot 6$ & $12 \cdot 1$ \\
\hline 1976 & 0 & $6 \cdot 1$ & 550 & 450 & 280 & 210 & 800 & 602 & $12 \cdot 1$ & $12 \cdot 0$ \\
\hline 1977 & 0 & $10 \cdot 4$ & 550 & 450 & 140 & 65 & 832 & -36 & $12 \cdot 0$ & $12 \cdot 4$ \\
\hline 1978 & 0 & $6 \cdot 9$ & 550 & 450 & 210 & 145 & 798 & 428 & $10 \cdot 7$ & $12 \cdot 6$ \\
\hline 1979 & 0 & $5 \cdot 3$ & 550 & 450 & 245 & 175 & 853 & 477 & $10 \cdot 1$ & $11 \cdot 8$ \\
\hline 1980 & 0 & $9 \cdot 8$ & 550 & 450 & 175 & 105 & 644 & 321 & $11 \cdot 2$ & $12 \cdot 1$ \\
\hline 1981 & 0 & $8 \cdot 2$ & 550 & 450 & 175 & 105 & 615 & 448 & $11 \cdot 1$ & $12 \cdot 0$ \\
\hline 1982 & 0 & $8 \cdot 6$ & 550 & 450 & 210 & 105 & 729 & 678 & $11 \cdot 2$ & $10 \cdot 8$ \\
\hline 1983 & 0 & $6 \cdot 5$ & 550 & 450 & 175 & 140 & 651 & 633 & $11 \cdot 6$ & $10 \cdot 5$ \\
\hline 1984 & 0 & $8 \cdot 7$ & 550 & 450 & 210 & 105 & 670 & 480 & $10 \cdot 5$ & $11 \cdot 8$ \\
\hline 1985 & 0 & $7 \cdot 2$ & 550 & 450 & 245 & 160 & 880 & 547 & $10 \cdot 2$ & $11 \cdot 9$ \\
\hline 1986 & 0 & $4 \cdot 8$ & 550 & 450 & 280 & 210 & 863 & 607 & $10 \cdot 7$ & $11 \cdot 7$ \\
\hline 1987 & 0 & $10 \cdot 6$ & 550 & 450 & 140 & 70 & 858 & 485 & $11 \cdot 0$ & $12 \cdot 1$ \\
\hline 1988 & 0 & $9 \cdot 5$ & 550 & 450 & 210 & 105 & 709 & 543 & $10 \cdot 8$ & $11 \cdot 8$ \\
\hline 1989 & 0 & $4 \cdot 7$ & 550 & 450 & 315 & 270 & 689 & 891 & $10 \cdot 9$ & $12 \cdot 0$ \\
\hline 1990 & 0 & $6 \cdot 3$ & 550 & 450 & 210 & 140 & 842 & 765 & $10 \cdot 9$ & $10 \cdot 3$ \\
\hline 1991 & 0 & $7 \cdot 2$ & 550 & 450 & 210 & 175 & 937 & 528 & $10 \cdot 5$ & $12 \cdot 1$ \\
\hline 1992 & 0 & $8 \cdot 8$ & 550 & 450 & 175 & 105 & 754 & 495 & $10 \cdot 5$ & $11 \cdot 4$ \\
\hline 1993 & 0 & $10 \cdot 8$ & 550 & 450 & 175 & 105 & 720 & 386 & $11 \cdot 2$ & $11 \cdot 5$ \\
\hline 1994 & 0 & $6 \cdot 9$ & 550 & 450 & 245 & 180 & 975 & 317 & $12 \cdot 0$ & $11 \cdot 2$ \\
\hline Average & 0 & 8.9 & 550 & 450 & 209 & 136 & 789 & 448 & $11 \cdot 1$ & $11 \cdot 7$ \\
\hline
\end{tabular}

The model scheduling management allowed an increase of the level of water depletion at harvest (Fig. 4). In 1981 and 1991, the level of water depletion at harvest was almost null with the standard strategy due to an important rainfall at the end of September and beginning of October. With the model strategy these values were much high delaying the risk of deep percolation and nitrogen losses during the refill period.

(a) Flowering

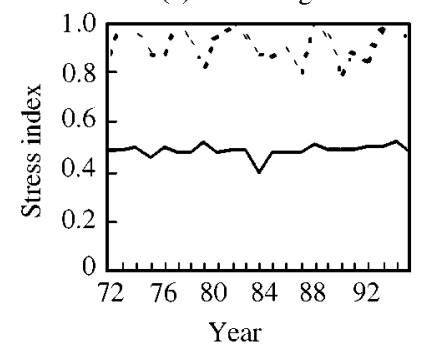

\subsubsection{Auzeville}

Table 1 shows that under the standard strategy an average of $209 \mathrm{~mm}$ of water was applied, with a minimum of $105 \mathrm{~mm}$ (1974) and a maximum of $315 \mathrm{~mm}$ (1989). The simulated yield was $11 \cdot 7 \mathrm{t} /$ ha on average. Figure 5 shows that the proportion of the average soil water used before irrigation was low (15-35\%) with a mean of $20 \%$. At harvest, this proportion was also low, ranging between

Fig. 2. Simulated average daily water stress intensities under non-irrigated conditions at (a) flowering and (b) grain-filling stages: 
(a) Before irrigation

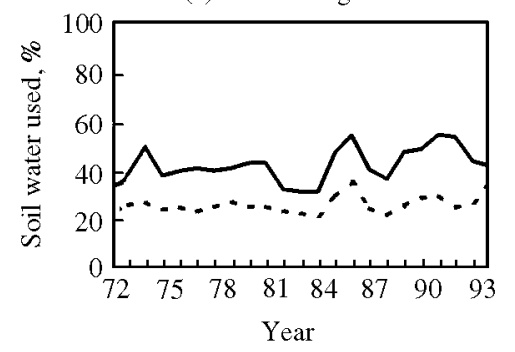

(b) Harvest

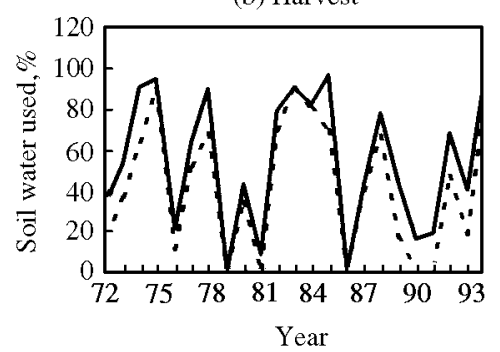

Fig. 3. Proportion of the average soil water used (a) before irrigation and at (b) harvest at Alvalade do Sado: standard strategy; , model strategy

0 and $50 \%$ with an average of $25 \%$ and according to the precipitation received after the last irrigation (Fig. 5).

Under the model strategy, the results show, for the same level of yield as obtained with the standard strategy, a reduction of water applied with an average of $136 \mathrm{~mm}$ applied and a minimum of $35 \mathrm{~mm}$ and a maximum of $270 \mathrm{~mm}$ (Table 1). It was possible to save $73 \mathrm{~mm}$ of water, the equivalent of two irrigations per year. The end of irrigation with the standard strategy was at the end of August or beginning of September (physiological maturity phase) and in the middle (exceptionally at the end) of August (beginning of physiological maturity phase) or exceptionally at the end of August with the model strategy. The early end of irrigation is attributed to the high level of water storage (proportion of water used was around $30 \%$ ), to the high probability of rain and to the low sensitivity of maize to water stress at this stage. The water savings with the model strategy are due to an increased use of soil water during the cycle and also to an earlier end of irrigation. Regarding the proportion of water used, values between 25 and $48 \%$ before irrigation and an average of $50 \%$ at harvest were simulated (Fig. 5).

The model scheduling management allowed an increase of the level of water depletion at harvest (Fig. 6). In 1984, the level of water depletion at harvest was almost nil with the standard strategy due to an important rainfall at the end of August and was about $100 \mathrm{~mm}$ with the model strategy. The risk of deep percolation and nitrogen losses during the refill period is then delayed with the model strategy.

\section{Discussion}

Although the results are from simulations, it is proved that the standard strategy is inadequate for the moderately deep soils of Lauragais/Auzeville and Alentejo/ Alvalade. The high level of soil water available in the soil profile is not used by the crop due to the imposed management. The model strategy is better adapted to schedule irrigation in both regions. It adjusts the irrigation frequency according to the crop water needs and the

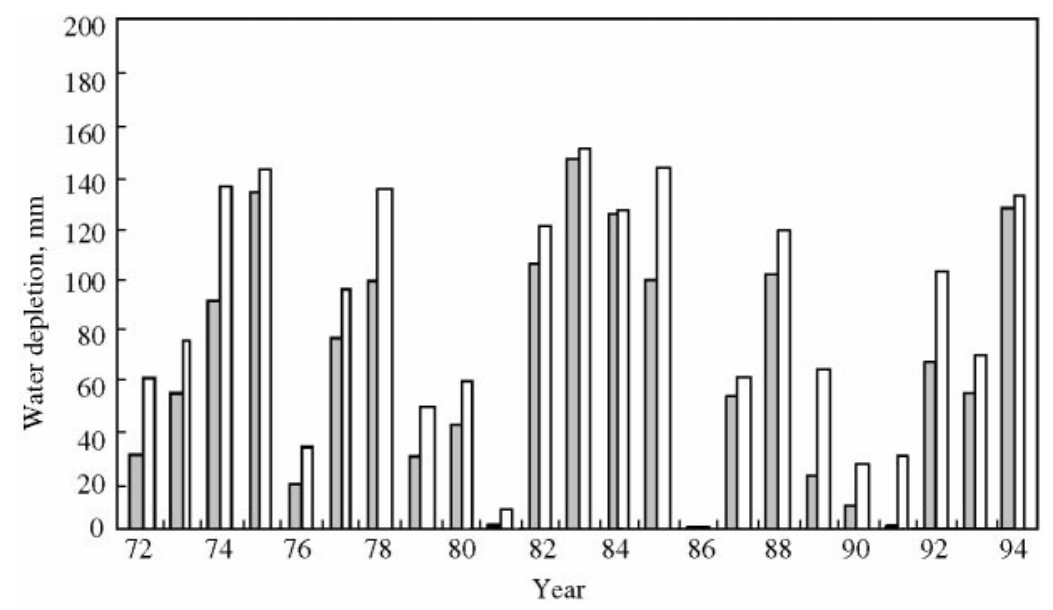

Fig. 4. Comparison between the level of water depletion at harvest at Alvalade do Sado: $\square$, standard; $\square$, model 

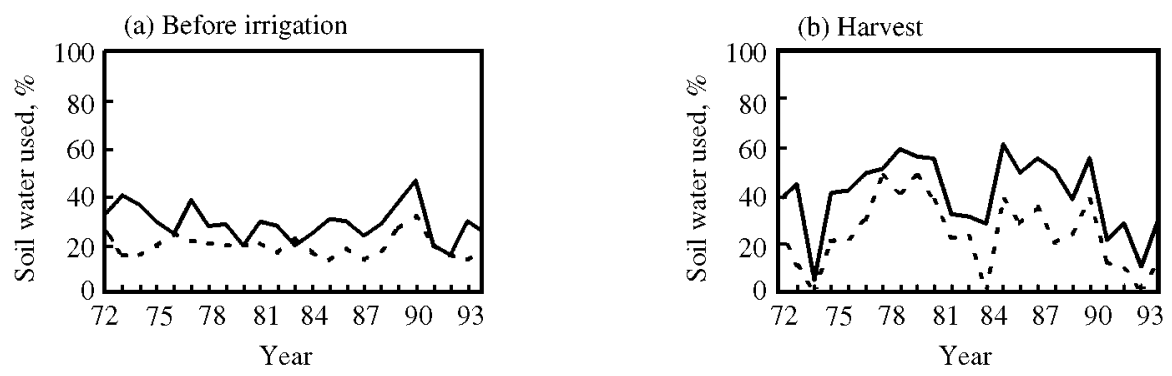

Fig. 5. Proportion of the average soil water used (a) before irrigation and at (b) harvest at Auzeville:

standard strategy; model strategy

available soil water in the profile. In consequence, irrigation is better scheduled, being delayed while there is water available in the profile for crop use, and initiated on time. In the process, less irrigation is needed and water is saved. These results are in agreement with the ones of Maertens et al. (1966) and Maertens \& Cabelguenne (1971) that have established that the proportion of soil water used by the crop before irrigation should be between 30 and $40 \%$. In fact, these values are more in agreement with that observed with the model strategy, instead of the $21-35 \%$ of soil water used before irrigation at Alvalade do Sado and $15-33 \%$ at Auzeville with the standard strategy. With both strategies, no stress was created for the same level of yield (Table 1) but the proportion of water soil use was considerably different.

Table 2 shows a comparison of irrigation scheduling simulated by EPIC-PHASE at Alvalade do Sado and at
Auzeville for the year 1990. At Alvalade do Sado, the beginning of irrigation occurs at the same date for both strategies because the rainfall was only $22 \mathrm{~mm}$ from sowing until 27 June. In July, there was less water applied $(100 \mathrm{~mm})$ with the model strategy compared to the standard strategy due to the absence of simulated water stress. During August, the number of irrigations were the same in both strategies due to the high sensibility of maize to water stress at the flowering and grain-filling phases. The end of irrigation with the model strategy occurred on the first of September and at that time with $48 \%$ of water had been used compared with the $30 \%$ used for standard strategy. At Auzeville, the scheduling of irrigations with the model delayed the first irrigation in response to rainfall that occurred in June and imposed also an early end to irrigation on 6 August instead of the predicted date of 16 August due to the rainfall that occurred in August.

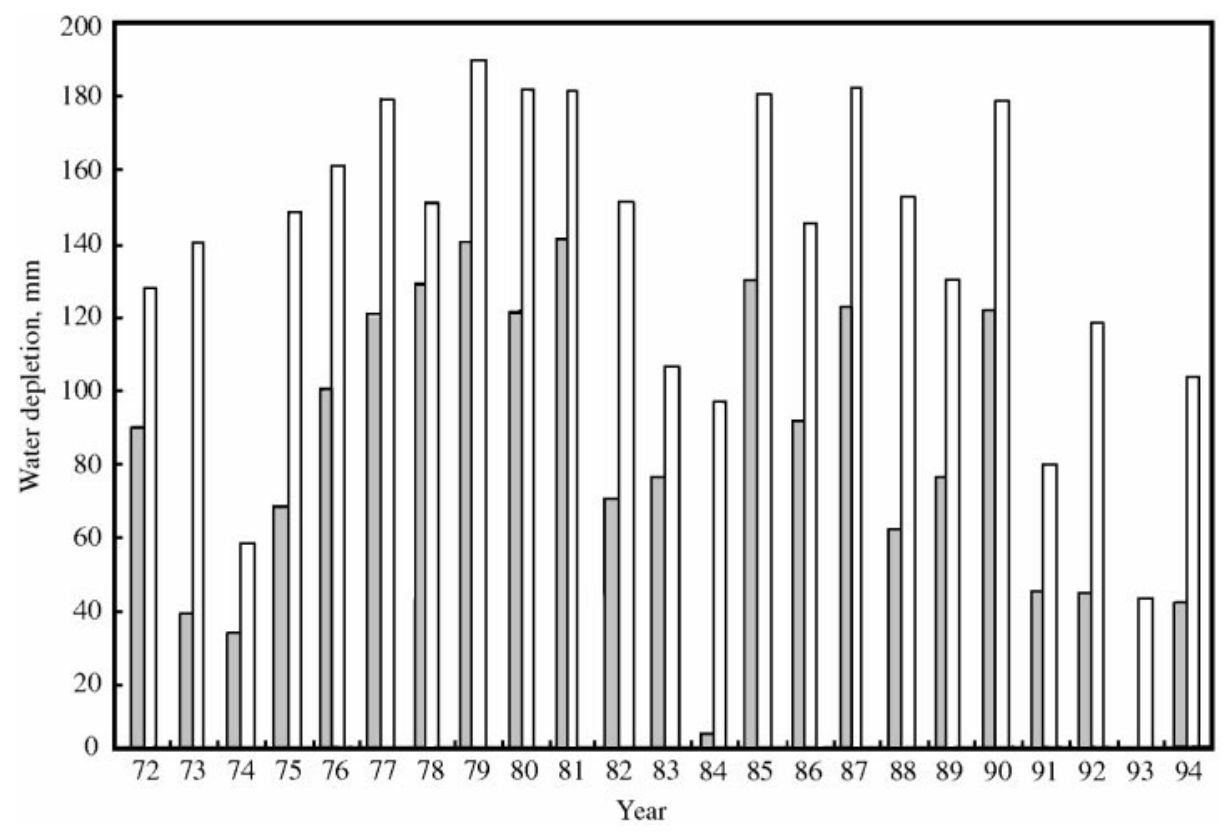

Fig. 6. Comparison between the level of water depletion at harvest at Auzeville; $\square$, standard; $\square$, model 
Table 2

Comparison of the standard and the model strategies for 1990 at Alvalade and at Auzeville

\begin{tabular}{|c|c|c|c|c|c|}
\hline \multicolumn{3}{|c|}{ Standard strategy } & \multicolumn{3}{|c|}{ Model strategy } \\
\hline Date & $\begin{array}{c}\text { Water } \\
\text { application, } \\
\mathrm{mm}\end{array}$ & $\begin{array}{c}\text { Soil water } \\
\text { used, } \%\end{array}$ & Date & $\begin{array}{c}\text { Water } \\
\text { application, } \\
\mathrm{mm}\end{array}$ & $\begin{array}{c}\text { Soil water } \\
\text { used, } \%\end{array}$ \\
\hline \multicolumn{6}{|l|}{ Alvalade } \\
\hline $27 / 6$ & 50 & 30 & $27 / 6$ & 50 & 35 \\
\hline $4 / 7$ & 50 & 20 & $10 / 7$ & 50 & 47 \\
\hline $11 / 7$ & 50 & 28 & $16 / 7$ & 50 & 41 \\
\hline $18 / 7$ & 50 & 28 & $26 / 7$ & 50 & 45 \\
\hline $24 / 7$ & 50 & 24 & $3 / 8$ & 50 & 47 \\
\hline $31 / 7$ & 50 & 30 & $10 / 8$ & 50 & 46 \\
\hline $7 / 8$ & 50 & 31 & $19 / 8$ & 50 & 45 \\
\hline $14 / 8$ & 50 & 30 & $25 / 8$ & 50 & 48 \\
\hline $21 / 8$ & 50 & 30 & $1 / 9$ & 50 & 48 \\
\hline $28 / 8$ & 50 & 30 & & & \\
\hline $4 / 9$ & 50 & 30 & & & \\
\hline Total & 550 & & & 450 & \\
\hline average & & 28 & & & 45 \\
\hline \multicolumn{6}{|c|}{ Auzeville } \\
\hline $1 / 7$ & 35 & 32 & $9 / 7$ & 35 & 42 \\
\hline $9 / 7$ & 35 & 23 & $17 / 7$ & 35 & 46 \\
\hline $17 / 7$ & 35 & 26 & $25 / 7$ & 35 & 47 \\
\hline $25 / 7$ & 35 & 37 & $6 / 8$ & 35 & 49 \\
\hline $6 / 8$ & 35 & 40 & & & \\
\hline $16 / 8$ & 35 & 40 & & & \\
\hline Total & 210 & & & 140 & \\
\hline average & & 33 & & & 46 \\
\hline
\end{tabular}

\section{Conclusions}

The EPIC-PHASE model proved suitable for scheduling irrigation and defining irrigation water applications better adapted to the crops, climatic changes and variability of the Mediterranean regions. It proved to be a versatile management tool, accommodating a wide range of climatic and soil characteristics such as the ones tested for in France and Portugal. Being the model developed and tested for a long period of time in France, the results are more reliable for the Auzeville site. The results are, however, very encouraging for Alentejo where the calibration was done successfully.

\section{References}

Cabelguenne M; Debaeke P (1995). Manuel d'utilization du modèle EWQTPR [EWQTPR: user's manual]. Publication interne Station d'Agronomie, INRA, Auzeville

Cabelguenne M; Debaeke P (1996). EPIC-PHASE temps réel: un modèle pour la conduite tactique de l'irrigation, [EPIC-
PHASE real time: a model for tactical irrigation management]. Comptes Rendus de l' Académie d'Agriculture de France, 82(4), 39-51

Cabelguenne M; Deumier J M (1996). EPIC-PHASE: un modèle pour l'exploration de stratégies d'irrigation, [EPICPHASE: a model to explore irrigation strategies]. Comptes Rendus de l' Académie d'Agriculture de France, 82(4), 59-71

Cabelguenne M; Puech J; Debaeke Ph; Bosc N (1997). Real time irrigation management using the EPIC-PHASE model and weather forecasts. Agricultural Water Management, 32, 227-238

Maertens C; Cabelguenne M (1971) Influence de l'irrigation sur les modalités d'utilisation de l'eau du sol par differentes cultures annuelles et pluriannuelles [The influence of irrigation on soil water use by different crop species]. Comptes Rendues de l'Académie d'Agriculture de France, 56, 926-936

Maertens C; Fioramonti S; Courau M; Puech J (1966). Modalités d'utilisation de l'eau du sol par le mais. Examen de la notion de réserve utilisable [The use of soil water by maize. Revision of the concept of water holding capacity]. Comptes Rendus de l'Académie d'Agriculture de France, 52, $1338-1348$ 
Santos A M M; Cabelguenne M; Santos F L; Oliveira M R; Serralheiro RP; Bica M A (1998). EPIC-PHASE: a model to explore irrigation strategies. Proceedings of EurAgEng Congress, Oslo, Norway, 24-27 August, pp 866-867

Santos A M M; Cabelguenne M; Santos F L; Oliveira M R; Serralheiro R P; Bica M A (1999). Testing the real time EPICPHASE (EWQTPR) model in a sub-humid Mediterranean environment. Proceedings of the International Symposium,
'New Approaches in Irrigation, Drainage and Flood Control Management'. Bratislava, Slovak Republic, 12-14 May, p 71

Santos F L; Serralheiro R P; Santos A M; Bica M A (1996). Maize tactical irrigation management in the southwest of Portugal using real time EPIC model. AgEng 96 Congress, Madrid, Spain, 23-26 September

Williams J R; Jones C A; Kiniry J R; Spanel D A (1989). The EPIC crop growth model. Transactions of the ASAE, 32(2), 497-511 